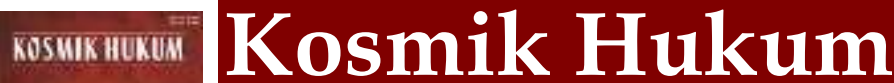

Fakultas Hukum

Universitas Muhammadiyah Purwokerto

Vol. 20 No. 2 (2020)

\section{Parpol, Pemilu dan Demokrasi: Dinamika Partai Politik dalam Sistem Pemilihan Umum di Indonesia Perspektif Demokrasi}

\section{Udiyo Basuki}

Fakultas Syari'ah dan HukumUIN Sunan Kalijaga

E-mail: udiyo.basuki@uin-suka.ac.id

\begin{abstract}
In a democratic country the relationship between the state and the people must be a reflection of a mutualistic symbiosis. This means that these relationships must be mutually dependent and mutually beneficial. This relationship will be evident when the political system developed by a country provides sufficient space for political activities in the community. This space for political activity will give color to democratic life in a country. The principle of democracy and people's sovereignty requires people's participation in the life of the state administration. People or citizens are not only objects, but subjects and play an important role in the life of the state. For this reason, the existence of a representative institution is an absolute that must be fulfilled in a democratic country with people's sovereignty. According to modern democracy, political parties, general elections and representative institutions are three institutions that cannot be separated from one another. That every political party will always strive to gain large popular support during general elections so that the representative institution can be dominated by the political party concerned.
\end{abstract}

Keywords: political parties, general elections, democracy.

\begin{abstract}
Abstrak
Dalam negara demokrasi hubungan antara negara dan rakyat harus merupakan cerminan dari simbiosis mutualistik. Artinya hubungan tersebut harus saling bergantung dan saling menguntungkan. Hubungan itu akan tampak jelas ketika sistem politik yang dikembangkan oleh suatu negara memberikan ruang gerak yang cukup bagi aktifitas politik di lingkungan masyarakat. Ruang gerak aktifitas politik inilah yang akan memberikan warna kehidupan demokrasi di dalam suatu negara.

Prinsip demokrasi dan kedaulatan rakyat menghendaki adanya keikutsertaan rakyat dalam kehidupan ketatanegaraan. Rakyat atau warga negara bukan hanya sebagai obyek, melainkan subyek dan ikut memainkan peranan penting dalam kehidupan kenegaraan. Untuk itu keberadaan lembaga perwakilan merupakan suatu kemutlakan yang harus dipenuhi dalam negara demokrasi yang berkedaulatan rakyat. Menurut paham demokrasi modern, partai politik, pemilihan umum dan lembaga perwakilan merupakan tiga institusi yang tidak dapat dipisahkan satu dengan yang lain. Bahwa setiap partai politik akan selalu berusaha untuk memperoleh dukungan rakyat yang besar pada saat pemilihan umum agar lembaga perwakilan dapat didominasi oleh partai politik yang bersangkutan.
\end{abstract}

Kata kunci: partai politik, pemilihan umum, demokrasi

Copyright@2020KosmikHukum. All rights reserved.

\section{Pendahuluan}

Pada umumnya negara modern di dunia menyatakan dirinya sebagai negara yang bersistem pemerintahan demokrasi, yakni sistem pemerintahan yang bersumber pada kedaulatan rakyat. Berdirinya suatu negara tidak dapat dipisahkan dari konsep tentang kedaulatan yang melekat pada negara yang bersangkutan. Kedaulatan merupakan unsur yang sangat penting dalam suatu negara. Hal ini mengingat negara adalah suatu organisasi kekuasaan yang merupakan alat untuk mencapai tujuan bersama.1

\footnotetext{
1 Dahlan Thaib, Kedaulatan Rakyat, Negara Hukum dan Konstitusi, (Yogyakarta: Liberty, 2000), p. 1.
} 
Seperti dipahami bersama demokrasi sebagai dasar hidup bermasyarakat dan bernegara mengandung pengertian bahwa rakyatlah yang memberikan ketentuan dalam masalah-masalah mengenai kehidupannya, termasuk dalam menilai kebijakan negara, karena kebijakan tersebut akan menentukan kehidupannya. Dengan demikian, negara yang menganut sistem demokrasi adalah negara yang diselenggarakan berdasarkan kehendak dan kemauan rakyat. Dari sudut organisasi, demokrasi berarti pengorganisasian negara yang dilakukan oleh rakyat sendiri atau atas persetujuan rakyat karena kedaulatan berada di tangan rakyat.2

Demokrasi sebagai suatu sistem telah dijadikan alternatif dalam berbagai tatanan tatanan aktifitas bermasyarakat dan bernegara di beberapa negara. Seperti diakui oleh Mahfud MD, setidaknya ada dua alasan dipilihnya demokrasi sebagai sistem bermasyarakat dan bernegara. Pertama, hampir semua negara di dunia telah menjadikan demokrasi sebagai asas yang fundamental, dan kedua, demokrasi sebagai asas kenegaraan secara esensial telah memberikan arah bagi peranan masyarakat untuk menyelenggarakan negara sebagai organsasi tertingginya. 3

Demokrasi sebagai dasar hidup bernegara memberi pengertian bahwa pada tingkat terakhir rakyat memberikan ketentuan dalam masalah-masalah pokok mengenai kehidupannya, termasuk dalam menilai kebijakan negara, karena kebijakan negara tersebut menentukan kehidupan rakyat. Jadi, negara demokrasi adalah yang diselenggarakan berdasarkan kehendak dan kemauan rakyat, atau jika ditinjau dari sudut organisasi, berarti suatu pengorganisasian negara yang dilakukan oleh rakyat sendiri atau asas persetujuan rakyat karena kedaulatan berada di tangan rakyat.4

Sebagai wujud dari ide kedaulatan rakyat, dalam sistem demokrasi harus dijamin bahwa rakyat terlibat penuh dalam merencanakan, mengatur, melaksanakan dan melakukan pengawasan serta menilai pelaksanaan fungsi-fungsi kekuasaan.5 Gagasan demokrasi merupakan wujud dari ketidakpuasan rakyat terhadap negara-negara yang menjalankan liberalisme dan utilitarianisme. Demokrasi merupakan jawaban atau solusi dari keinginan untuk menciptakan negara yang tidak berpihak kepada siapapun, tetapi rakyat yang menjadi penentu kemajuan suatu bangsa.6

Pelaksanaan paham demokrasi dewasa ini tidak mungkin lagi dilaksanakan secara langsung (direct democracy). Paham demokrasi secara formal dan prosedural dilaksanakan melalui mekanisme perwakilan (indirect democracy atau representative democracy). 7 Demokrasi perwakilan sebagai sistem demokrasi modern terdiri dari tiga macam, yaitu demokrasi dengan sistem parlementer, demokrasi dengan pemisahan kekuasaan, dan demokrasi yang dikontrol oleh rakyat secara langsung melalui referendum dan inisiatif.8

2 Abdul Rozak, dkk (ed.), Civic Education: Demokrasi, Hak Asasi Manusia dan Masyarakat Madani, (Jakarta: ICCE UIN Syarif Hidayatullah bekerja sama dengan The Asia Foundation dan Prenada Media, 2003), p. 111.

Moh. Mahfud MD, Demokrasi dan Konstitusi di Indonesia, (Yogyakarta: Liberty, 1993), p. 18.

Deliar Noer, Pengantar ke Pemikiran Politik, (Jakarta: Rajawali, 1985), p. 207.

Jimly Asshiddiqie, Konstitusi dan Konstitusionalisme di Indonesia, (Jakarta: Sekretariat Jenderal dan Kepaniteraan MK RI, 2006), p. 115-116.

6 Jazim Hamidi dan Mustafa Lutfi, Civic Education: Antara Realitas Politik dan Implementasi Hukumnya, (Jakarta: Gramedia Pustaka Utama, 2010), p. 184.

7 B. Hestu Cipto Handoyo, Hukum Tata Negara Indonesia, (Yogyakarta: Universitas Atma Jaya, 2009), p. 227. Demokrasi langsung, kiranya pada waktu sekarang kecil sekali ada negara yang masih menjalankannya, dalam arti terhadap keseluruhan masalah-masalah kenegaraan, atau boleh dikatakan tidak ada, dikarenakan pertama, pada umumnya wilayah suatu negara relatif luas dan kemungkinan tidak terdiri dari satu daratan, melainkan terdiri atas banyak pulau-pulau. Kedua, pada umumnya rakyat suatu negara sudah berjumlah besar. Ketiga, masalah kenegaraan bersifat politis, jumlahnya semakin meningkat dan kompleks serta rumit, sehingga rakyat awam akan mendapat kesulitan apabila dimintai pendapatnya secara langsung (di tempat) untuk menilai dan menelaahnya, guna dipakai sebagai dasar untuk mengambil keputusan, terutama bagi negara-negara yang tingkat pendidikannya belum begitu maju. Endang Sulistyaningsih, Pemilu dan Perkembangan Demokrasi di Indonesia, (Salatiga: Widya Sari Press, 2003), p. 59-60.

8 Jimly Asshiddiqie, "Partai Politik dan Pemilihan Umum sebagai Instrumen Demokrasi”, dalam Jurnal Konstitusi Vol. 3, No. 4, Desember 2006, p. 6. 
Salah satu konsekuensi dari pelaksanaan demokrasi perwakilan adalah adanya jarak antara rakyat yang berdaulat dengan pemerintahan yang dibentuk untuk melaksanakan kedaulatan tersebut. Tanpa adanya jaminan mekanisme partisipasi rakyat dalam negara sebagai bentuk pelaksanaan kedaulatan rakyat, konsep kedaulatan dapat dikebiri dan terjebak dalam pengertian kedaulatan rakyat yang otoriter. Maka diperlukan instrumen untuk menjembatani rakyat dengan wakil-wakilnya baik di parlemen maupun yang duduk sebagai pejabat publik Pemerintahan berupa mekanisme dan institusi bagi ekspresi dari kehendak yang diwakili. Jika tidak demikian, sistem perwakilan dapat berubah menjadi manipulasi dan paksaan (coercion) oleh pemegang kekuasaan.9 Paling tidak terdapat dua instrumen yang saling berhubungan, tandas Jimly,10 yaitu keberadaan partai politik dan pelaksanaan pemilihan umum.

\section{Hasil dan Pembahasan}

\section{Partai Politik, Pemilihan Umum dan Lembaga Perwakilan}

a. Partai Politik dan Demokrasi

Untuk menjembatani antara pemerintah dan rakyat, sebagai wujud bekerjanya demokrasi diperlukan adanya partai politik. Sistem demokrasi tidak mungkin berjalan tanpa adanya partai politik. Pembuatan keputusan secara teratur hanya mungkin dilakukan jika ada pengorganisasian berdasarkan tujuan-tujuan kenegaraan. Tugas partai politik adalah menata aspirasi rakyat untuk dijadikan public opinion yang lebih sistematis sehingga dapat menjadi dasar pembuatan keputusan yang teratur.11 Dalam negara modern, jumlah pemilih yang sangat besar dan kepentingannya bervariasi sehingga perlu mengelolanya untuk menjadi keputusan. Dengan demikian partai politik berperan besar dalam proses seleksi baik pejabat maupun substansi kebijakan.12

Oleh Carl. J. Friedrich, partai politik didefinisikan sebagai sekelompok manusia yang teroganisir secara stabil dengan tujuan merebut dan mempertahankan penguasaan pemerintah bagi pemimpin partainya, dan berdasarkan penguasaan ini memberikan kepada anggota partainya kemanfaatan yang bersifat ideal maupun materiil.13 Sigmund Neumann memberi pengertian sebagai organisasi dari aktivis-aktivis politik yang berusaha untuk menguasai kekuasaan pemerintahan serta merebut dukungan rakyat atas dasar persaingan melawan golongan atau golongan-golongan lain yang tidak sepaham.14

Bagi Miriam Budiardjo, partai politik adalah suatu kelompok yang teroganisir yang angota-anggotanya mempunyai orientasi, nilai-nilai dan cita-cita yang sama dengan tujuan untuk memperoleh kekuasaan politik dan merebut kedudukan politik (biasanya), dengan cara konstitusional guna melaksanakan kebijaksanaan-kebijaksanaan mereka.15 Karenanya, partai

$9 \quad$ Alistair Clarck, Parties and Political Linkage: Towards a Comprehensive Framework for Analysis, Paper prepared for PSA Annual Conferense, University of Leicester, 15-17 April 2003, p. 3-4. Bahwa demokrasi tumbuh sejalan dengan pertumbuhan dan perkembangan masyarakat. Semakin tinggi tingkat kompleksitas kehidupan masyarakat maka semakin rumit dan tidak sederhana pula demokrasi didefinisikan. Salah satu hasil akomodasi pendefinisian demokrasi terhadap tingkat perkembangan masyarakat adalah semakin tergesernya kriteria partisipasi langsung rakyat dalam formulasi kebijakan oleh model perwakilan. Selain itu penempatan posisi dan peran penguasaatau negarajuga senantiasa mengalami pendefinisian ulang, bergeser dari posisi dan peran "penjaga malam" atau "pemadam kebakaran" ke arah posisi dan peran yang lebih besar dan menentukan, baca Eep Saefulloh Fatah, Masalah dan Prospek Demokrasi di Indonesia, (Jakarta: Ghalia Indonesia, 1995), p. 5-6.

10 Jimly Asshidiqie, "Partai Politik dan Pemilihan Umum", p. 7. Pelaku utama demokrasi adalah rakyat, yaitu orang yang selalu diatasnamakan namun tidak pernah ikut menentukan. Menjaga proses demokratisasi adalah memahami secara benar hak-hak yang dimiliki, menjaga hak-hak itu agar siapapun menghormatinya dan melawan siapaun yang berusaha melanggar hak-hak itu. Menjaga proses demokratisasi adalah menyatakan sikap secara rasional dan matang sambil ikhlas menerima orang dengan sikap yang berbeda. Dan, pemilu adalah salah satu wahana untuk menjaga proses demokratisasi. Eep Saifulloh Fatah, Mencintai Indonesia dengan Amal: Refleksi atas Fase awal Demokratisasi, (Jakarta: Republika, 2005), p. 91.

11 R. Kranenberg dan Tk. B. Sabaroedin, Ilmu Negara Umum, Cetakan Kesebelas, (Jakarta: Pradnya Paramita, 1990$),$ p. 8.

12 RM MacIver, The Modern State, First Edition, (London: Oxford University Press, 1955), p. 194.

13 Miriam Budiardjo, Dasar-dasar Ilmu Politik, (Jakarta: Gramedia Pustaka Utama, 1986), p. 160.

14 Ibid., p. 161.

$15 \quad$ Ibid. 
politik mempunyai posisi dan peranan yang penting dalam sistem demokrasi. Partai memainkan peran penghubung yang sangat strategis antara proses-proses pemerintahan dengan warga negara. Banyak yang menyatakan bahwa partai politiklah yang sebetulnya menentukan demokrasi.16 Karena itu partai politik merupakan pilar dalam sistem politik yang demokratis.17

Tujuan pembentukan suatu partai politik di samping tujuan utamanya, merebut, mempertahankan ataupun menguasai pemerintahan suatu negara, juga dapat dilihat dari aktivitas yang dilakukan oleh partai politik. Menurut Rusadi Kartaprawira ditinjau dari aktivitas yang dilakukan oleh partai politik, maka umumnya tujuan yang diemban partai politik meliputi pertama, berpartisipasi dalam sektor pemerintahan, dalam arti mendudukkan orang-orangnya menjadi pejabat pemerintahan sehingga dapat turut serta mengambil atau menentukan keputusan politik atau output pada umumnya. Kedua, berusaha melakukan pengawasan, bahkan oposisi bila perlu terhadap kelakuan, tindakan, kebijakan para pemegang otoritas (terutama dalam keadaan mayoritas pemerintahan tidak berada dalam tangan partai politik yang bersangkutan. Ketiga, berperan untuk dapat memadukan tuntutan-tuntutan yang masih mentah, sehingga partai politik bertindak sebagai penafsir kepentingan dengan mencanangkan isu-isu politik yang dapat dicerna dan diterima oleh masyarakat secara luas.18 Miriam Budiardjo, menggambarkan adanya 4 (empat) fungsi politik, yaitu meliputi sarana: (i) komunikasi politik (political communication), (ii) sosialisasi politik (political socialization), (iii) rekruitmen politik (political recruitment), (iv) pengatur konflik (conflict management).19

Menurut Jimly,20 keempat fungsi di atas sama-sama terkait satu dengan yang lainnya. Sebagai sarana komunikasi politik, partai berperan sangat penting dalam upaya mengartikulasikan kepentingan kepentingan (interest articulation) atau political interests yang terdapat atau kadang-kadang tersembunyi dalam masyarakat. Partai politik juga berperan melakukan sosialisasi politik. Ide, visi dan kebijakan strategis yang menjadi pilihan partai politik dimasyarakatkan kepada konstituen untuk mendapatkan feedback berupa dukungan dari masyarakat luas. Adapun fungsi rekruitmen politik, dikarenakan partai politik dibentuk memang dimaksudkan untuk menjadi kendaraan yang sah untuk menyeleksi kader-keder pemimpin negara pada jenjang-jenjang dan posisi-posisi tertentu. Sedangkan sebagai pengatur atau pengelola konflik, partai berperan sebagai sarana agregasi kepentingan (aggregation of interests) yang menyalurkan ragam kepentingan yang berbeda-beda itu melalui saluran kelembagaan politik partai.

Karena sedemikian banyak jenis dan bentuk partai politik yang hidup dan berkembang dalam kehidupan kenegaraan, maka partai politik dapat diklasifikasikan dalam 2 (dua) kategori besar.21 Pertama, klasifikasi partai politik ditinjau dari komposisi dan fungsi keanggotaannya dapat dikelompokkan dalam 2 (dua) jenis, yaitu partai massa dan partai kader. Partai massa yaitu partai politik yang lebih mengutamakan kekuatan berdasarkan keunggulan jumlah anggota. Oleh karena itu biasanya terdiri dari pendukung dari berbagai aliran politik dalam masyarakat yang sepakat berada di bawahnya dalam memperjuangkan suatu program yang biasanya luas dan agak kabur. Kedua, partai kader, yaitu partai politik yang lebih mementingkan keketatan organisasi dan disiplin kerja dari anggota-anggotanya. Pemimpin partai biasanya menjaga

16 Bahkan oleh Yves Meny dan Andrew Knapp dikatakan "A democratic system without political parties or with a single party is impossible or at any rate hard to imagine", Yves Meny and Andrew Knapp, Government and Politics in Western Europe: Britain, France, Italy, Germany, Third Edition, (Oxford: Oxford University Press, 1968), p. 86. Lihat, Udiyo Basuki, "Sistem Kepartaian dan Implikasinya bagi Masa Depan Demokrasi di Indonesia", dalam Jurnal Panggung Hukum Vol. 2, No. 1, Januari 2016, p. 2

17 E.E. Schattschneider, The Semisovereign People: A Realist's View of Democracy in America, (Illionois: The Dryden Press Hinsdale, 1975), p. 58.

18 Rusadi Kartasasmita, Sistem Politik Indonesia: Suatu Model Pengantar, Cet. V, (Bandung: Sinar Baru, 1988), p. 62.

19 Miriam Budiardjo, Dasar-dasar Ilmu Politik, p. 163-164. Jimly menerangkan bahwa fungsi partai politik tersebut menurut istilah Yves Meny dan Andrew Knapp mencakup fungsi (i) mobilisasi dan integrasi, (ii) sarana pembentukan pengaruh terhadap perilaku memilih (voting patterns), (iii) sarana rekruitmen politik, dan (iv) sarana elaborasi pilihan-pilihan kebijakan. Jimly Asshiddiqie, "Partai Politik dan Pemilihan Umum", p. 8.

$20 \quad$ Ibid., p. 8-10.

21 Miriam Budiardjo, Dasar-dasar Ilmu Politik, p. 166-167. 
kemurnian doktrin partai yang dianut dengan jalan mengadakan saringan calon-calon anggota secara ketat.

Ditinjau dari sifat dan orientasinya, partai politik dapat dikelompokkan menjadi 2 (dua) jenis, yaitu partai lindungan dan partai ideologi. Partai lindungan (patronage party) yaitu suatu partai politik yang pada umumnya memiliki organisasi nasional yang kendor dengan disiplin lemah. Tujuan utama partai politik jenis ini adalah memenangkan pemilu untuk anggotaanggota yang dicalonkan. Partai semacam ini biasanya hanya giat melaksanakan aktifitasnya menjelang pemilu saja. Partai ideologi (partai asas) adalah suatu partai politik yang mempunyai pandangan hidup yang digariskan dalam kebijaksanaan pemimpin dan beropedoman pada displin partai yang kuat dan mengikat.22

Dalam kehidupan politik kenegaraan, pada prinsipnya dikenal adanya 3 (tiga) sistem kepartaian, yaitu pertama, sistem partai tunggal (one party system). Istilah ini dipergunakan untuk partai politik yang benar-benar merupakan satu-satunya dalam suatu negara, maupun untuk memberikan istilah partai politik yang mempunyai kedudukan dominan di antara partai politik yang lain. Kedua, sistem dua partai (two party system). Dalam sistem ini partai-partai politik yang ada di negara dengan jelas dibagi menjadi partai politik yang berkuasa karena menang dalam pemilu dan partai oposisi karena kalah dalam pemilu. Ketiga, sistem banyak partai (multy party system). Pada umumnya sistem kepartaian semacam ini muncul karena adanya keanekaragaman sosial budaya dan politik yang terdapat dalam suatu negara. 23

\section{b. Pemilihan Umum dan Demokrasi}

Pemilu adalah arena kompetisi untuk mengisi jabatan-jabatan politik di pemerintahan yang didasarkan pada pilihan formal warga Negara yang memenuhi syarat. Peserta pemilu dapat berupa perseorangan dan partai politik tetapi yang paling utama adalah partai politik. Partai politik mengajukan kandidat dalam pemilu untuk kemudian dipilih oleh rakyat.24

Pada jaman modern ini pemilu menempati posisi penting karena terkait dengan beberapa hal. Pertama, pemilu menjadi mekanisme terpenting bagi keberlangsungan demokrasi perwakilan. Ia adalah mekanisme tercanggih yang ditemukan agar rakyat tetap berkuasa atas dirinya. Perkembangan masyarakat yang pesat, jumlah yang banyak, persebaran yang meluas dan aktivitas yang dilakukan semakin beragam menjadikan kompleksitas persoalan yang dihadapi rakyat semakin variatif. Kondisi tersebut tidak memungkinkan rakyat untuk berkumpul dalam satu tempat dan mendiskusikan masalah-masalah yang mereka hadapi secara serius dan tuntas. Akhirnya muncul demokrasi perwakilan sebagai keniscayaan dengan pemilu sebagai mekanisme untuk memilih wakilnya. 25

Kedua, pemilu menjadi indikator negara demokrasi. Bahkan, tidak ada satupun negara yang mengklaim dirinya demokratis tanpa melaksanakan pemilu sekalipun negara itu pada hakekatnya adalah otoriter. Ketika perspektif Schumpetarian tentang demokrasi, yaitu demokrasi sebagai 'metode politik' mendominasi teorisasi demokrasi maka pemilu menjadi elemen paling penting dari ukuran negara demokrasi. Prezeworski dan rekan-rekannya mendefinisikan demokrasi sebagai ‘sekadar rezim yang menyelenggarakan pemilihan-pemilihan umum untuk mengisi jabatan-jabatan pemerintahan' (dengan ketentuan bahwa persaingan yang sebenarnya mensyaratkan adanya oposisi yang memiliki kesempatan memenangkan jabatan publik, serta bahwa posisi kepala eksekutif dan kursi legislatif diisi melalui pemilu).26 Sementara itu, Dahl menyebutkan dua dari enam ciri lembaga-lembaga politik yang dibutuhkan oleh

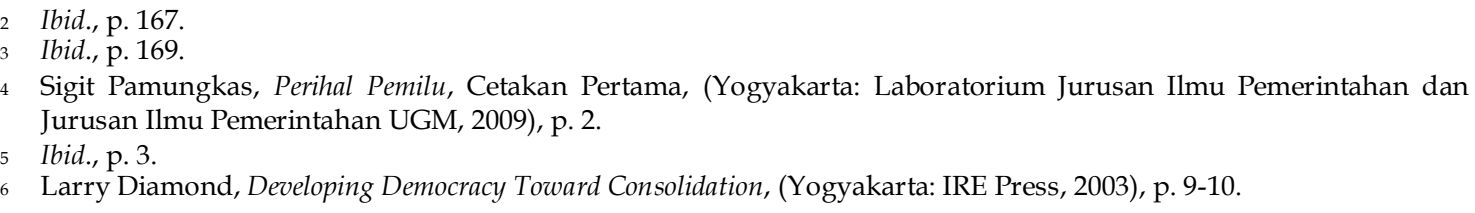


Kosmik Hukum Vol. 20 No. 2 (2020): 82-95

E-ISSN: 2655-9242 | P-ISSN: 1411-9781

DOI: 10.30595/kosmikhukum.v20i2.8321

demokrasi skala besar adalah berkaitan dengan pemilu, yaitu para pejabat yang dipilih dan pemilu yang bebas, adil dan berkala.27

Ketiga, pemilu penting dibicarakan juga terkait dengan implikasi-implikasi yang luas dari pemilu. Dalam gelombang ketiga demokratisasi pemilu menjadi suatu cara untuk memperlemah dan mengakhiri rezim-rezim otoriter.28 Pada fase ini Huntington menyebut pemilu sebagai alat serta tujuan demokratisasi. Pernyataan tersebut berangkat dari kenyataan tumbangnya penguasa-penguasa otoriter akibat dari pemilu yang mereka sponsori sendiri karena mencoba memperbaharui legitimasi melalui pemilu. 29

Maka pentingnya pemilihan umum diselenggarakan secara berkala dikarenakan oleh beberapa hal. Pertama, pendapat atau aspirasi rakyat mengenai berbagi aspek kehidupan bersama dalam masyarakt bersifat dinamis dan berkembang dari waktu ke waktu. Dalam jangka waktu tertentu dapat saja terjadi bahwa sebagian besar rakyat berubah pendapatnya mengenai sesuatu kebijakan negara. Kedua, di samping pendapat rakyat dapat berubah dari waktu ke waktu, kondisi kehidupan bersama dalam masyarakat dapat pula berubah, baik karena dinamika dunia internasional ataupun karena faktor dalam negeri sendiri, baik karena faktor internal manusia maupun karena faktor eksternal manusia. Ketiga, perubabahan-perubahan aspirasi dan pendapat rakyat juga dapat dimungkinkan terjadi karena pertambahan jumlah penduduk dan rakyat yang dewasa. Mereka itu, terutama para para pemilih baru (new voters) atau pemilih pemula, belum tentu mempunyai sikap yang sama dengan orang tua mereka sendiri. Lagi pula, keempat, pemilihan umum perlu diadakan secara teratur untuk maksud menjamin terjadinya pergantian kepemimpinan negara, baik di cabang kekuasaan eksekutif maupun legislatif.30

Sehingga, masih menurut Jimly, 31 dapat dikatakan tujuan penyelenggaraan pemilu itu ada 4 (empat), yaitu untuk (i) memungkinkan terjadinya peralihan kepemimpinan secara tertib dan damai, (ii) memungkinkan terjadinya pergantian pejabat yang akan mewakili kepentingan rakyat di lembaga perwakilan, (iii) melaksanakan prinsip kedaulatan rakyat, dan (iv) melaksanakan prinsip hak-hak asasi warga negara.

Oleh karena pemilihan umum adalah salah satu cara untuk menentukan wakil-wakil rakyat yang akan duduk dalam lembaga perwakilan, maka dengan sendirinya terdapat berbagai sistem pemilihan. Sistem ini berbeda satu sama lain, tergantung dari sudut mana hal itu dilihat. Dari sudut kepentingan rakyat, apakah rakyat dipandang sebagai individu yang bebas untuk menentukan pilihannya, dan sekaligus mencalonkan dirinya sebagai calon wakil rakyat, ataukah rakyat hanya dipandang sebagai anggota kelompok yang sama sekali tidak berhak menentukan siapa yang akan menjadi wakilnya di lembaga perwakilan, atau juga tidak berhak mencalonkan diri sebagai wakil rakyat.

Berdasar hal tersebut, sistem pemilu dapat dibedakan dalam 2 (dua) macam, yaitu sistem pemilihan organis dan sistem pemilihan mekanis. Sistem pemilihan organis yakni mengisi keanggotaan lembaga perwakilan melalui pengangkatan atau penunjukan. Sedangkan sistem pemilihan mekanis ini sering disebut juga pemilihan umum.32

Sistem pemilihan yang bersifat organis, menempatkan rakyat sebagai sejumlah individuindividu yang hidup bersama dalam berbagai persekutuan hidup berdasarkan genealogis (rumah tangga, keluarga), fungsi tertentu (ekonomi, industry), lapisan-lapisan sosial (buruh, tani, cendekiawan), dan lembaga-lembaga sosial (universitas). Kelompok-kelompok dalam masyarakat dilihat sebagai suatu organisme yang terdiri atas organ-organ yang mempunyai kedudukan dan fungsi tertentu dalam totalitas organisme dalam totalitas organisme, seperti komunitas atau persekutuan-persekutuan hidup. Persekutuan-persekutuan inilah yang

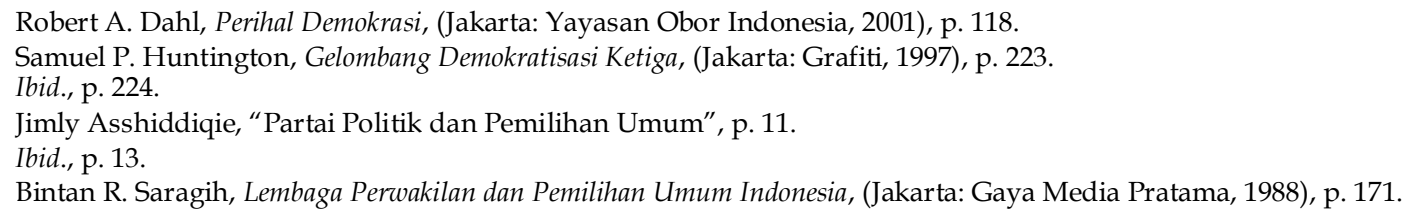


mempunyai hak pilih untuk mengutus wakil-wakilnya kepada badan perwakilan rakyat. Sedangkan sistem pemilihan mekanis mencerminkan pandangan yang melihat rakyat sebagai individu-individu yang sama. Baik aliran liberalisme, sosialisme maupun komunisme samasama mendasarkan diri pada pandangan mekanis ini. Berangkat dari sistem pemilihan mekanis inilah kemudian dikenal adanya 2 (dua) sistem pemilihan umum, yaitu sistem perwakilan distrik dan sistem perwakilan berimbang. 33

Sistem yang pertama, yaitu sistem distrik, biasa dinamakan juga sebagai sistem single member constitutiencies,34 atau sistem the winner's take all. Dinamakan demikian, karena wilayah negara dibagi dalam distrik-distrik pemilihan atau daerah-daerah pemilihan (dapil) atau constituencies yang jumlahnya sama dengan jumlah anggota lembaga perwakilan rakyat yang diperlukan untuk dipilih. Beberapa ahli menyebutnya juga dengan istilah sistem plurality atau majority, serta ada yang menyebutnya dengan single member constituency, karena yang dipilih sebagai wakil rakyat dari suatu daerah ditentukan oleh siapa yang memperoleh suara terbanyak atau suara mayoritas untuk daerah itu, sekalipun kemenangannya hanya bersifat mayoritas relatif. Sistem ini terbagi atas variasi first past the post, alternative vote, two-round system, block vote dan party block vote.

Sedangkan pada sistem kedua, yaitu sistem perwakilan berimbang atau perwakilan proporsional (multy member constituency),35 persentase kursi di lembaga perwakilan rakyat dibagikan kepada tiap-tiap partai politik, sesuai dengan persentase jumlah suara yang diperoleh tiap-tiap partai politik. Disebut "sistem berimbang" karena merupakan sistem pemilihan dimana kursi yang tersedia di parlemen dibagikan kepada partai-partai politik (organisasi peserta pemilu) sesuai dengan imbangan suara yang didapat oleh partai-partai politik (organisasi peserta pemilu) yang bersangkutan.36Jadi, dalam sistem ini, proporsi kursi yang dimenangkan oleh sebuah partai politik dalam sebuah wilayah pemilihan akan berbanding seimbang dengan proporsi suara yang diperoleh partai tersebut dalam pemilihannya. Sistem proporsional dapat dilaksanakan dengan variasi proportional representation dan single transferable vote.

Di luar kedua sistem pemilihan umum di atas, sekarang dikenal juga sistem ketiga, yakni sistem campuran, yang merupakan penerapan secara bersama-sama sistem plurality/ mayority dengan sistem proporsional dalam suatu negara. Sistem ini meliputi parallel system dan mixed member proportional.37 Dan keempat, sistem pemilu di luar ketiga sistem mainstream, yang merupakan sistem campuran antara distrik dan proporsional dengan variasi single nontransferable vote, limited vote dan borda count.38

\section{Partai Politik dan Pemilihan Umum di Indonesia \\ a. Pemilihan Umum Tahun 1955}

Keberadaan partai politik di Indonesia sesungguhnya dimulai pada permulaan abad ke20, berbarengan dengan pencanangan kebijakan pemerintah Hindia Belanda yang banyak dipengaruhi oleh politik etis. Maka berbagai asosiasi bercorak etnis, kebudayaan dan keagamaan bermunculan sejak tahun 1905. Berbagai partai politik kemudian bermunculan setelah Gubernur Jenderal Idenburg memberikan keleuasaan kepada Sarekat Islam bergerak secara lokal, karena ia mengira organisasi ini tidak akan terlibat dalam aktivitas politik. Partai-partai lain juga kemudian bermunculan dalam kurun 1910-1930, seperti Indische Partij, ISDV (yang kemudian

\footnotetext{
33 Jimly Asshiddiqie, "Partai Politik dan Pemilihan Umum", p. 15-19, Sigit Pamungkas, Perihal Pemilu, p. 27-30, Endang Sulistyaningsih, Pemilu dan Perkembangan, p. 7-15, B. Hestu Cipto Handoyo, Hukum Tata Negara, p. 244-246, Ni'matul Huda, Hukum Tata Negara Indonesia, (Jakarta: RajaGrafindo Perkasa, 2010), p. 274-277.

34 G.J. Wolhoff, Pengantar Ilmu Hukum Tata Negara Republik Indonesia, (Jakarta: Timun Mas N.V., 1955), p. 10.

35 J.A. Corry, Democratic Government and Politics, (Toronto: University of Toronto Press, 1960), p. 237.

36 Dahlan Thaib dan Ni'matul Huda (ed.), Pemilu dan Lembaga Perwakilan dalam Ketatanegaraan Indonesia, (Yogyakarta: Jurusan HTN Fakultas Hukum UII, 1993), p. 22.

37 Baca Sigit Pamungkas, Perihal Pemilu, p. 36-37.

$38 \quad$ Ibid., p. 37.
} 
berubah menjadi Partai Komunis Hindia) dan PNI (Partai Nasional Indonesia) yang didirikan oleh Soekarno pada tahun 1927.39

Partai-partai yang lahir, kendatipun tumbuh dan berkembang berdasarkan ideologi politik yang berbeda-beda, namun memiliki kontribusi yang besar dalam menumbuhkan semangat nasionalisme Indonesia. Sarekat Islam (yang kemudian menjadi Partai Syarikat Islam Indonesia), Partai Islam Indonesia dan Partai Penyadar adalah partai-partai dengan ideologi politik Islam. PNI, PRI (Partai Rakyat Indonesia) dan Parindra (Partai Indonesia Raya) berideologi nasionalisme, sedangkan Partai Komunis Hindia (kemudian menjadi Partai Komunis Indonesia) berideologi komunisme.

Setelah memasuki masa kemerdekaan, berdasar pada Maklumat Pemerintah tertanggal 3 Nopember 1945 yang ditandatangani Wakil Presiden Moh. Hatta, partai-partai politk semakin bertumbuh. Dan sejak saat itulah Indonesia menganut sistem multi partai yang ditandai dengan munculnya 10 partai politik yang berbasis aliran (ideologi).

Dalam maklumat yang ditandatangani atas saran Badan Pekerja Komite Nasional Indonesia Pusat (KNIP) itu ditegaskan bahwa pemerintah 'menyukai timbulnya partai-partai politik, karena dengan adanya partai-partai itulah dapat dipimpin ke jalan yang teratur segala aliran paham yang ada dalam masyarakat'. Pemerintah juga berharap pembentukan partai-partai itu selesai sebelum diadakan pemilihan umum pada bulan Januari 1946.

Dikarenakan berbagai problem kebangsaan di era demokrasi liberal yang membawa negara pada instabilitas politik berkepanjangan, 40 maka pemilu yang direncanakan digelar 5 (lima) bulan sesudah kemerdekaan, akhirnya baru dapat dilaksanakan pada tahun 1955. Pemilu yang mendasarkan pada Undang-undang Nomor 7 Tahun 1955 tentang Pemilihan Anggota Konstituante dan Anggota DPR inilah yang memungkinkan dilaksanakannya pemilihan umum nasional yang pertama pada 29 September 1955.

Pemilu tahun 1955 ini diadakan untuk memilih anggota-anggota DPRD tingkat II, anggota-anggota DPR tingkat I, anggota-anggota DPR dan anggota Konstituante Republik Indonesia. Pemilihan umum ini menganut sistem pemilihan umum proporsional murni, dengan stelsel daftar dan dengan kemungkinan para pemilih memilih seorang calon tertentu.41Pemilu yang diikuti oleh tidak kurang dari 39 partai politik dan beberapa kontestan lain ini,42 melahirkan "empat besar" yaitu PNI, Masyumi (Majelis Syuro Muslim Indonesia), NU (Nahdlatul Ulama) dan PKI.

Tahun 1960 tidak lagi digelar pemilu. Pemilu 1955 tidak dilanjutkan sesuai jadwal pada lima tahun berikutnya, 1960. Hal ini dikarenakan pada tanggal 5 Juli 1959 Presiden Soekarno mengeluarkan. Dekrit Presiden yang isinya membubarkan Konstituante dan pernyataan kembali ke UUD 1945. Kemudian pada 4 Juni 1960, Soekarno membubarkan DPR hasil pemilu 1955, setelah sebelumnya dewan legislatif itu menolak RAPBN yang diajukan pemerintah. Presiden

39 Yusril Ihza Mahendra, Dinamika Tata Negara Indonesia: Kompilasi Aktual Masalah Konstitusi, Dewan Perwakilan dan Sistem Kepartaian, (Jakarta: Gema Insani Press, 1996), p. 177-178.

40 Instabilitas politik ini tercermin dari panjangnya persiapan pelaksanaan pemilu tahun 1955 yang disiapkan dan diselenggarakan oleh 3 (tiga) kabinet yang berbeda. Persiapannya dilakukan oleh Kabinet Wilopo, sedangkan pelaksanaannya dilakukan oleh Kabinet Ali Sastroamidjojo dan Kabinet Burhanuddin Harahap. Kabinet Wilopo mempersiapkan rencana undang-undang pemilu, Kabinet Ali Sastroamidjojo melaksanakan pemilu sampai tahap kampanye, kemudian digantikan Kabinet Burhanuddin Harahap yang melaksanakan tahapan selanjutnya, yaitu hari -H pencoblosan sampai pemilu selesai. Daniel Dhakidae, "Pemilihan Umum di Indonesia: Saksi Pasang Naik dan Surut Partai Politik", dalam Prisma No. 9, Tahun X, September 1981, p. 24.

41 Sri Soemantri M., Bunga Rampai Hukum Tata Negara Indonesia, (Bandung: Alumni, 1992), p. 150.

42 Jumlah peserta pemilu untuk memilih anggota DPR adalah 118 kontestan. Secara kategoris, kontestan pemilu tersebut dapat dikelompokkan menjadi 4 (empat) kelompok besar yakni (1) kelompok partai politik sebanyak 39 parpol, (2) kelompok organisasi sebanyak 46, (3) kelompok perorangan sebanyak 59 dan (4) kelompok kumpulan pemilih sebanyak 56 . Terkait wakil perorangan jumlah terbesar dari daerah pemilihan Jawa Tengah, diikuti Sumatera Tengah dan Sumatera Utara. Sementara itu peserta pemilu untuk memilih anggota Konstituante tidak sebanyak peserta pada pemilu DPR. Peserta pemilu Konstituante hanya diikuti 91 kontestan. Peserta pemilu Konstituante pada dasarnya menjadi peserta pada pemilu DPR. Herbert Feith, Pemilihan Umum 1955 di Indonesia, (Jakarta: Gramedia, 1955), p. 33. 
Soekarno secara sepihak, melalui dekrit tersebut membentuk DPR-Gotong Royong (DPR) dan MPR Sementara (MPRS) yang semua anggotanya diangkat Presiden. 43

\section{b. Pemilihan Umum di Era Orde Baru}

Sepanjang Orde Baru berkuasa, Indonesia telah menyelenggarakan pemilu sebanyak 6 (enam) kali yaitu tahun 1971, 1977, 1982, 1987, 1992, dan 1997. Meskipun demikian, pelaksanaan pemilu di bawah Orde Baru memiliki karakter berbeda dengan pemilu yang dikenal negaranegara demokrasi pada umumnya. Jika di negara demokrasi karakter pemilu dibangun atas prinsip free and fair baik dalam struktur dan proses pemilu, sebaliknya Orde Baru justru menghindari penerapan prinsip tersebut. Yang terjadi kemudian adalah ketidakseimbangan kontestasi antar peserta dan hasil pemilu tidak mencerminkan aspirasi dan kedaulatan rakyat. Pelaksanaan pemilu diatur melalui cara-cara tertentu untuk kelanggengan kekuasaan Orde Baru itu sendiri.44

Ada beberapa hal mendasar yang menjadikan pemilu-pemilu selama Orde Baru berkuasa tidak dikategorikan sebagai pemilu yang demokratis.45 Pertama, terlalu dominannya peranan pemerintah, dan sebaliknya amat minimnya keterlibatan masyarakat hampir di semua tingkatan kelembagaan maupun proses pemilu. Dominasi pemerintah yang terlalu besar terlihat dalam postur kelembagaan penyelenggara pemilu dari tingkat pusat hingga struktur kepanitiaan terendah yang didominasi pemerintah. Kalaupun melibatkan unsur di luar pemerintah tidak lebih hanya aksesoris belaka.

Kedua, proses pemilu tidak berlangsung fair karena adanya pemihakan pemerintah kepada salah satu organisasi peserta pemilu (OPP), yaitu Golkar. Birokrasi dengan 'monoloyalitas'-nya dan militer mem-back-up Golkar untuk mencapai kemenangan. Ketiga, monopoli pemerintah dalam salah satu proses pemilu yang terpenting, yakni penghitungan suara. Pada tahap ini, hampir tidak ada peluang bagi OPP di luar Golkar mengikuti dan terlibat secara penuh dalam penghitungannya, kecuali di tingkat tempat pemungutan suara.

Ketika Presiden Soeharto memegang tampuk kekuasaan, pemilu pertama kali berdasarkan Tap MPRS Nomor XI Tahun 1966 seharusnya diselenggarakan selambat-lambatnya 6 Juli 1968. Namun Soeharto kemudian menyatakan pemilu tidak dapat dilaksanakan pada waktu yang telah ditentukan. MPRS akhirnya menjadwal ulang pemilu dengan menetapkan pemilu digelar paling lambat 5 Juli 1971.

Berdasarkan Undang-Undang No. 15 Tahun 1969, menggunakan sistem perwakilan berimbang dengan stelsel daftar, Pemilu 1971 akhirnya digelar untuk memilih anggota-anggota Badan Permusyawaratan/ Perwakilan Rakyat dari tingkat Pusat, tingkat I (propinsi) dan tingkat II (kabupaten/ kotamadya) se-Indonesia.46 Pemilu yang diikuti 10 partai politik ini menempatkan Golongan Karya (Golkar) sebagai pemenang. Mahfud MD menyebutkan, 47 kemenangan Golkar pada Pemilu 1971 telah memantapkan dominasi pemrintah atas semua spektrum dan proses politik di Indonesia. Dan sejak itu pula langgam otoriter pemerintah Orde Baru semakin menegaskan dirinya.

Hasil Pemilu 1971 yang menunjukkan kemenangan Golkar diikuti oleh Parmusi, NU dan PNI ini tidak lepas dari jasa ABRI yang dibantu oleh pemerintah. Dalam perkembangan lebih lanjut, pemerintah melakukan penyederhanaan partai politik secara melembaga melalui proses fusi. Partai yang berbasis Islam seperti NU, Parmusi, PSSI, dan Partai Islam digabung menjadi

43 Teguh Purnomo dan Sukarno, Mengawal Demokrasi dengan Ikhlas, (Yogyakarta: Pustaka Pelajar, 2016), p. 37-38.

44 Sigit Pamungkas, Perihal Pemilu, p. 75.

45 Syamsudin Haris, "Struktur, Proses dan Fungsi Pemilihan Umum: Catatan Pendahuluan" dalam Syamsudin Haris (ed.), Menggugat Pemilihan Umum Orde Baru, (Jakarta: Yayasan Obor, 1998), p. 11-12.

46 S. Toto Pandoyo, Ulasan terhadap Beberapa Ketentuan UUD 1945: Sistem Politik dan Perkembangan Kehidupan Demokrasi, (Yogyakarta: Liberty, 1981), p. 153. Budiman B. Sagala, Praktek Sistem Ketatanegaraan Menurut UUD 1945, (Jakarta: Ghalia Indonesia, 1981), p. 72.

47 Moh. Mahfud MD, Politik Hukum di Indonesia, (Jakarta: Pustaka LP3ES Indonesia, 1998), p. 222-223. 
Kosmik Hukum Vol. 20 No. 2 (2020): 82-95

E-ISSN: 2655-9242 | P-ISSN: 1411-9781

DOI: 10.30595/kosmikhukum.v20i2.8321

PPP (Partai Persatuan Pembangunan). Partai yang berbasis sosialis dan nasionalis seperti Parkindo, Partai Katolik, PNI, Murba dan IPKI menjadi PDI (Partai Demokrasi Indonesia).

Kemudian dengan diberlakukannya Undang-Undang No. 3 Tahun 1975, Pemilu 1977 dan 1982 hanya diikuti oleh 3 (tiga) peserta yang masing-masing mempunyai ciri-ciri pertama, PPP dengan ciri ke-Islaman dan ideologi Islam. Kedua, Golkar dengan ciri kekaryaan dan keadilan sosial, dan ketiga, PDI yang bercirikan kebangsaan (nasionalisme) dan keadilan.

Selanjutnya pada Pemilu 1987 dan 1992 dengan diberlakukannya Undang-Undang No. 3 Tahun 1985, partai politik dan Golkar ditetapkan hanya mempergunakan satu-satunya asas, yaitu Pancasila dengan tujuan agar setiap kontestan pemilu lebih berorientasi kepada program kerja masing-masing. Penerapan asas tersebut kemudian berlangsung sampai dengan pelaksanaan Pemilu 1997.

Fakta memperlihatkan bahwa selama Pemilu Orde Baru, Golkar selalu dominan. Dalam Pemilu 1971 Golkar meraih 62,8\% suara, Pemilu 1977 62,1\%, Pemilu 1982 64,3\%, Pemilu 1987 73,2\%, Pemilu 1992 68,1\% dan pada Pemilu 1997 kemenangan Golkar mencapai 70,2\% raihan suara.

Jika dilihat dominasi Golkar dalam keseluruhan pemilu Orde Baru maka format kepartaian yang terbentuk dapat dikatakan sebagai sistem kepartaian hegemonik. Ciri dari tipe kepartaian ini adalah adanya sebuah partai atau sebuah koalisi partai yang mendominasi proses politik dalam suatu negara dalam kurun waktu yang lama.48Bahwa partai hegemonik tidak akan membiarkan terjadinya kompetisi, baik yang berssifat formal maupun aktual. Partai-partai lain diadakan hanyalah sebagai kelas dua dan sekadar diberi lisensi, karena mereka tidak akan diperkenankan untuk berkompetisi yang antagonistik dan basis yang sama. Impliksinya adalah partai hegemonik akan tetap berkuasa disukai atau tidak, tidak aka nada sanksi yang membuat partai hegemonik responsif, tidak hanya perubahan kekuasaan, segala bentuk premis tentang kompetisipun dikesampingkan. 49

Era Orde Baru mengalami antiklimaks kekuasaan setelah pada akhir tahun 1997 Indonesia mengalami krisis moneter yang selanjutnya berkembang menjadi krisis multidimensi karena terperangkap hutang luar negeri yang besar dan maraknya praktik Korupsi, Kolusi dan Nepotisme (KKN) yang melibatkan pejabat birokrasi dan pengusaha.

\section{c. Pemilu Sesudah Era Reformasi}

Setelah Presiden Soeharto mundur dari kekuasaannya pada tanggal 21 Mei 1998, jabatan presiden digantikan oleh Wakil Presiden Bacharuddin Jusuf Habibie. Atas desakan publik agar pemilu dipercepat, Pemilu 1999 kemudian dilaksanakan pada 7 Juni 1999, atau 13 bulan masa kekuasaan Habibie, tiga tahun lebih cepat dari waktu yang seharusnya dijadwalkan, yaitu tahun 2002. Diselenggarakannya Pemilu 1999 adalah karena alasan untuk memperoleh pengakuan atau kepercayaan dari publik, termasuk dunia internasional, karena pemerintahan dan lembagalembaga lain yang merupaka produk Pemilu 1997 sudah dianggap tidak dipercaya. Hal ini kemudian dilanjutkan dengan penyelenggaraan Sidang Umum MPR untuk memilih Presiden dan Wakil Presiden baru. Ini berarti bahwa pemilu dipercepat yang terjadi bukan hanya akan digantinya keanggotaan DPR dan MPR sebelum selesai masa kerjanya, tetapi Presiden Habibie sendiri memangkas masa jabatannya yang seharusnya berlangsung sampai tahun 2003.

Pemilu 1999 sering disebut sebagai pemilu transisi untuk masuk format politik yang lebih demokratis. Pemilu menjadi semacam simpang jalan; apakah proses politik itu terus setia pada jalur demokratisasi, berbelok jalan atau bahkan berbalik arah sama sekali. Pengalaman transisi berbagai negara di dunia menunjukkan kemana pendulum transisi bergerak dari hasil pemilu. 50

48 Baca Sigit Pamungkas, Perihal Pemilu, p. 84.

49 Affan Gaffar, "Sistem Kepartaian yang Hegemonik dan Terobosan Demokrasi di Indonesia", dalam Amir Effendi Siregar, et al (ed.), Percikan Pemikiran Fisipol UGM tentang Pembangunan, (Yogyakarta: Fisipol UGM, 1990), p. 62. Baca juga Affan Gaffar, Javaness Voters, (Yogyakarta: Gadjah Mada UP, 1992), p. 36-37.

50 Hairus Salim (peny.), Tujuh Mesin Pendulang Suara, (Yogyakarta: LKiS, 1999), p. 1. 
Pemilu 1999 juga bisa disebut sebagai pemilu anti-tesis pemilu-pemilu Orde Baru. Banyak aspek bertolak belakang dengan masa Orde Baru. Disebut demikian karena beberapa hal. Pertama, liberalisasi politik yang melahirkan 48 peserta pemilu menjadikan pemilu hampir diikuti oleh seluruh spektrum ideologi yang pernah ada di pentas politik Indonesia, tanpa terkecuali. Kedua, pemilu dibangun di atas spirit baru yaitu Luber plus Jurdil. Diketahui bahwa pemilu masa Orde Baru dibangun atas asas Luber (langsung, umum, bebas, rahasia) dengan mengabaikan aspek Jurdil (jujur dan adil) bagi penyelenggara maupun peserta pemilu. Ketiga, adanya netralitas birokrasi. Birokrasi yang selama Orde Baru dimobilisasi untuk mendukung dan menjadi bagian integral dari Golkar berusaha dinetralkan untuk tidak memihak salah satu partai politik.51

Meski demikian, di luar dimensi ideal Pemilu 1999, ada beberapa catatan yang menjadikan kualitas pemilu tercemari. Pertama, masih terdapat kebijakan bernuansa Orde Baru yaitu diijinkannya militer dalam lembaga perwakilan rakyat. Ditetapkan bahwa 38 kursi DPR dan 10\% untuk masing-masing DPRD propinsi dan kabupaten/ kota diberikan cuma-cuma kepada militer. Bukan hanya persoalan jumlah, tapi di atas segalanya kehadirannya menghancurkan sebagian dasar legitimasi DPR sebagai lembaga perwakilan rakyat.52

Kedua, hal lain yang turut merusak penyelenggaraan pemilu adalah komposisi penyelenggara pemilu, Komisi Pemilihan Umum (KPU) yang partisan. Komposisi anggota KPU terdiri atas 2 (dua) unsur, yaitu perwakilan pemerintah dan perwakilan partai-partai peserta pemilu. Komposisi ini menjadikan KPU bertindak tidak independen dan terjadi konflik kepentingan. Tindakan KPU yang menyerahkan tanggung jawab pengesahan hasil pemilu kepada presiden karena jumlah anggota KPU yang menandatangani tidak mencapai 2/3 anggota, keputusan KPU yang membatalkan berlakunya penggabungan suara yang sah (stembus accord) kelompok 8 (delapan) partai Islam dan kelompok PDKB, PBI, dan PADI, serta ambiguitas KPU yang melarang partai melibatkan kadernya yang menteri tetapi justru memperkenankan anggota KPU wakil partai politik menjadi calon legislatif dan melakukan kampanye adalah beberapa hal yang menjadikan KPU berperan dalam cidera Pemilu 1999.53

Pemilu 1999 menghasilkan 5 (lima) besar yaitu PDIP (Partai Demokrasi Indonesia Perjuangan) 33,8\%, Partai Golkar 22,5\%, PKB (Partai Kebangkitan Bangsa) 12,6\%, PPP 10,7\%, dan PAN (Partai Amanat Nasional) mendapat raihan suara 7,1\%.

Berikutnya, proses pemilihan presiden dan wakil presiden oleh MPR yang berlangsung alot, akhirnya menetapkan Abdurahman Wahid (Gus Dur) sebagai presiden dan Megawati Soekarnoputeri sebagai wakil presiden. Selama duet Abdurrahman Wahid-Megawati tensi politik sangat tinggi. Pada masa ini sering terjadi bongkar pasang kabinet dan konflik eksekutif versus legislatif yang kemudian berujung pada dijatuhkannya Abdurrahman Wahid sebagai presiden karena tuduhan korupsi dana Bulog. Tidak kurang 14 kali terjadi pergantian menteri dan 5 kasus yang menyebabkan ketegangan antara DPR dan Presiden.54Setelah turunnya Abdurrahman Wahid, Megawati naik menjadi presiden dengan didampingi Hamzah Haz, ketua umum PPP, sebagai wakil presiden.

Secara umum, dapat disimpulkan Pemilu 1999 telah menjadikan partai sebagai kekuatan politik yang sangat kuat, tidak hanya di parlemen bahkan di kabinet. Masa ini dapat disebut sebagai masa kekuasaan partai politik meskipun di bawah sistem presidensiil.

Pemilu 2004, dibagi atas 2 (dua) jadwal, yaitu pemilu untuk memilih 550 anggota DPR, 128 anggota DPD dan anggota DPRD, serta pemilu untuk memilih Presiden dan Wakil Presiden secara langsung, yang merupakan pengalaman pertama bagi Indonesia. Pada pemilu yang diikuti oleh 24 partai politik ini menempatkan Partai Golkar sebagai partai yang mendominasi perolehan pemilu legislatif. Sedangkan hasil pemilu presiden dan wakil presiden yang

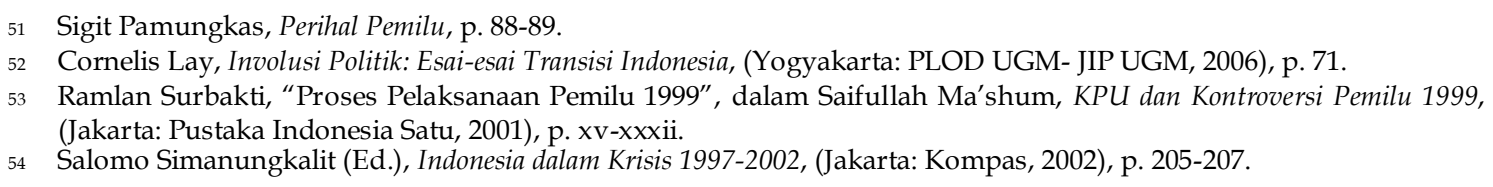


dilaksanakan 2 putaran, karena tidak ada pasangan yang mendapat suara mayoritas mutlak, akhirnya dimenangkan oleh pasangan Susilo Bambang Yudoyono dan Yusup Kalla.

Pemilu 2004 merupakan pemilu yang diselenggarakan sesudah UUD 1945 diamandemen 4 kali, yang tentu saja mempengaruhi sistem ketatanegaraan, dan pada gilirannya berimplikasi terhadap pelaksanaan pemilu. 55 Daniel Sparringa,56 menyebutkan empat kali amandemen UUD 1945 memberikan beberapa hasil penting yaitu pengadopsian sistem bikameral, pengakhiran MPR sebagai super body dan dilakukannya pemilihan presiden secara langsung. Terhadap lembaga negara, amandemen ini menghapus DPA (dewan Pertimbangan Agung) dan kursi bagi TNI di DPR. Selain penghapusan, juga dibentuk lembaga baru yaitu MK (Mahkamah Konstitusi), KY (Komisi Yudisial) dan KPU (Komisi Pemilihan Umum).

Terhadap ketatanegaraan, amandeman tersebut memberikan implikasi adanya adaptasi terhadap Trias Politica, yaitu MK, KY dan KPU sebagai auxiliary institution. Parlemen terdiri dari dua kamar dengan DPR sebagai wakil rakyat melalui partai politik dan DPD mewakili daerah melalui calon perorangan. Sementara MPR adalah lembaga joint session. Posisi presiden menjadi sangat kuat karena dipilih langsung oleh rakyat, sehingga parlemen tidak bisa menjatuhkannya hanya karena kebijakan yang berseberangan dengan DPR. Keabsahan impeachment terhadap presiden yang diajukan DPR ditentukan oleh MK. MA mengurusi lembaga peradilan konvensional, sementara MK mengurusi sengketa kostitusional antar lembaga negara dan publik. KY mengawasi para hakim dan mengoperasikan lembaga peradilan konvensional.57

Sukses Pemilu 1999 dan Pemilu 2004, menurut Setiawan Djodi,58 hanyalah satu proses dari rivoltare, bahwa pemilu memang melahirkan pemerintah baru yang legitimate, yang memperoleh kepercayaan rakyat, sayangnya pemilu itu belum melahirkan satu sistem baru yang lebih baik. Pemilu yang jujur dan adil merupakan satu siklus sendiri; yaitu dari krisis kepercayaan rakyat menuju kembalinya legitimasi itu.

Pemilu 2009 berlangsung pada 9 April 2009 untuk memilih 560 anggota DPR, 132 anggota DPD dan anggota DPRD, kemudian disusul pemilu untuk memilih Presiden dan Wakil Presiden. Pada pemilu ini Partai Demokrat memenangkan suara terbanyak, diikuti Partai Golkar dan PDIP. Pada pemilihan presiden dan wakil presiden terpilih pasangan Susilo Bambang Yudoyono dan Boediono.

Pemilu 2014 dilaksanakan pada 9 April 2014 diikuti oleh 12 partai politik untuk memilih 560 anggota DPR, 132 anggota DPD, serta anggota DPRD. Pada tahap pemilihan presiden dan wapres, terpilih sebagai pemenangnya pasangan Joko Widodo dan Yusup Kalla. Sedangkan Pemilu 2019 yang merupakan pemilu serentak yang pertama kali diselenggarakan di Indonesia digelar pada 17 April 2019 diikuti oleh 14 partai politik. Pada pemilihan presiden dan wakil presiden, pasangan Joko Widodo dan Ma'ruf Amin berhasil memenangkan kontestasi untuk menjabat sebagai presiden dan wakil presiden 2019-2024.

\section{Penutup}

Demokrasi adalah kerangka sosial dan politik dari suatu masyarakat yang didasarkan pada prinsip kebebasan dan kesamaan. Hal ini dikarenakan demokrasi itu sendiri didasarkan pada falsafah bahwa manusia adalah makhluk yang bebas dan sederajat dengan manusia

\footnotetext{
55 Udiyo Basuki, “Dinamika Konstitusi Indonesia (Refleksi Yuridis atas Proses dan Hasil Amandemen UUD 1945)”, dalam Jurnal Sosio-Religia Vol. 1, No. 4, Agustus 2002, p. 19-37, Udiyo Basuki, "Struktur Ketatanegaraan: Analisis Yuridis atas Dinamika Lembaga-lembaga Negara Pasca Amandemen UUD 1945”, dalam Jurnal In Right Vol. 1, No. 1, November 2011, p. 85-111, Udiyo Basuki, "Quo Vadis UUD 1945: Refleksi 67 Tahun Indonesia Berkonstitusi", dalam Jurnal Supremasi Hukum Vol. 1, No. 1, Juni 2012, p. 1-24.

56 Daniel Sparingga, Pemilu 2004: Taksonomi Tema dan Isu Relevan, dalam M. Faried Cahyono dan Lambang Trijono, Pemilu 2004: Transisi Demokrasi dan Kekerasan, (Yogyakarta: CSPS (Center for Security and Peace Studies), 2004), p. 1112.

$57 \quad$ Ibid., p. 12.

58 Setiawan Djodi, Reformasi dan Elemen-elemen Revolusi, (Jakarta: Elex Media Komputindo, 2009), p. 41.
} 
lainnya. Manusia adalah makhluk yang bebas, dalam arti tidak diciptakan sebagai robot yang sumber kegiatan-kegiatannya ditentukan oleh kekuatan di luar dirinya.

Pemilihan umum yang diselenggarakan untuk memilih anggota lembaga perwakilan, yang di dalamnya berisi kegiatan partai-partai politik adalah salah satu kriteria demokrasi. Pemilihan umum dianggap sebagai tahap paling awal dari berbagai rangkaian kehidupan ketatanegaraan yang demokratis dan merupakan motor penggerak mekanisme sistem politik demokrasi. Dalam konteks Indonesia, dengan pemilihan umum inilah pengisian badan-badan atau organ-organ negara dimulai, baik organ negara yang melaksanakan kedaulatan rakyat, maupun organ negara yang melaksanakan pemerintahan.

Bagi partai politik, tujuan pemilihan umum adalah untuk memperoleh dukungan sebanyak mungkin suara rakyat sehingga diharapkan dapat merebut dan atau mempertahan kedudukannya dalam sistem pemerintahan negara secara konstitusional. Bagi warga negara (rakyat), tujuan pemilihan umum selain umtuk memilih wakil rakyat yang duduk dalam lembaga perwakilan maupun pemimpin negara (pemerintahan) adalah juga dipergunakan sebagai sarana untuk melakukan evaluasi terhadap kebijakan negara dalam melaksanakan kehendak rakyat dalam kurun waktu tertentu. Sehingga, negara akan selalu dapat didesak untuk mempertanggungjawabkan segenap kebijakannya kepada rakyat. Negara dibuat menjadi accountable terhadap rakyat.

Karenanya pemilihan umum secara berkala harus dilaksanakan. Dalam perkembangannya kemudian tentu muncul berbagai usul perbaikan berdasarkan rekam jejak penyelenggaraannya. Dalam demokrasi Indonesia pemilihan umum telah dilangsungkan dengan berbagai dampak yang ditimbulkannya. Dampak tersebut menimbulkan berbagai reaksi dalam masyarakat. Beberapa diantaranya yang merupakan topik hangat setiap periode pemilu adalah usulan pembenahan, yaitu perubahan dan perbaikan sistem pemilihan umum baik dari sisi regulasi, penyelenggaraan, sampai kepada mekanisme penyelesaian sengketa.

\section{Daftar Pustaka}

Asshiddiqie, Jimly, Konstitusi dan Konstitusionalisme di Indonesia, Jakarta, Sekretariat Jenderal dan Kepaniteraan MK RI, 2006.

Asshiddiqie, Jimly, "Partai Politik dan Pemilihan Umum sebagai Instrumen Demokrasi", dalam Jurnal Konstitusi Vol. 3, No. 4, Desember 2006.

Basuki, Udiyo, "Dinamika Konstitusi Indonesia (Refleksi Yuridis atas Proses dan Hasil Amandemen UUD 1945)", dalam Jurnal Sosio-Religia Vol. 1, No. 4, Agustus 2002.

Basuki, Udiyo, "Quo Vadis UUD 1945: Refleksi 67 Tahun Indonesia Berkonstitusi", dalam Jurnal Supremasi Hukum Vol. 1, No. 1, Juni 2012.

Basuki, Udiyo, "Sistem Kepartaian dan Implikasinya bagi Masa Depan Demokrasi di Indonesia", dalam Jurnal Panggung Hukum Vol. 2, No. 1, Januari 2016.

Basuki, Udiyo, "Struktur Ketatanegaraan: Analisis Yuridis atas Dinamika Lembaga-lembaga Negara Pasca Amandemen UUD 1945", dalam Jurnal In Right Vol. 1, No. 1, November 2011.

Budiarjo, Miriam, Dasar-dasar Ilmu Politik, Jakarta, Gramedia Pustaka Utama, 2000.

Cahyono, M. Faried dan Lambang Trijono, Pemilu 2004: Transisi Demokrasi dan Kekerasan, Yogyakarta, CSPS (Center for Security and Peace Studies), 2004.

Clarck, Alistair, Parties and Political Linkage: Towards a Comprehensive Framework for Analysis, Paper prepared for PSA Annual Conferense, University of Leicester, 15-17 April 2003.

Corry, J.A., Democratic Government and Politics, Toronto, University of Toronto Press, 1960.

Dahl, Robert A., Perihal Demokrasi, Jakarta, Yayasan Obor Indonesia, 2001. 
Kosmik Hukum Vol. 20 No. 2 (2020): 82-95

E-ISSN: 2655-9242 | P-ISSN: 1411-9781

DOI: $10.30595 /$ kosmikhukum.v20i2.8321

Daniel Dhakidae, Daniel, "Pemilihan Umum di Indonesia: Saksi Pasang Naik dan Surut Partai Politik", dalam Prisma No. 9, Tahun X, September 1981.

Diamond, Larry, Developing Democracy Toward Consolidation, Yogyakarta, IRE Press, 2003.

Djodi, Setiawan, Reformasi dan Elemen-elemen Revolusi, Jakarta, Elex Media Komputindo, 2009.

Fatah, Eep Saefulloh, Masalah dan Prospek Demokrasi di Indonesia, Jakarta, Ghalia Indonesia, 1995.

Fatah, Eep Saifulloh, Mencintai Indonesia dengan Amal: Refleksi atas Fase awal Demokratisasi, Jakarta, Republika, 2005.

Feith, Herbert, Pemilihan Umum 1955 di Indonesia, Jakarta, Gramedia, 1955.

Gaffar, Affan, Javaness Voters, Yogyakarta, Gadjah Mada UP, 1992.

Hamidi, Jazim dan Mustafa Lutfi, Civic Education: Antara Realitas Politik dan Implementasi Hukumnya, Jakarta, Gramedia Pustaka Utama, 2010.

Handoyo, B. Hestu Cipto, Hukum Tata Negara Indonesia, Yogyakarta, Universitas Atma Jaya, 2009.

Haris, Syamsudin (ed.), Menggugat Pemilihan Umum Orde Baru, Jakarta, Yayasan Obor, 1998.

Huda, Ni'matul, Hukum Tata Negara Indonesia, Jakarta, RajaGrafindo Perkasa, 2010.

Huntington, Samuel P., Gelombang Demokratisasi Ketiga, Jakarta, Grafiti, 1997.

Kartasasmita, Rusadi, Sistem Politik Indonesia: Suatu Model Pengantar, Cet. V, Bandung, Sinar Baru, 1988.

Kranenberg, R., dan Tk. B. Sabaroedin, Ilmu Negara Umum, Cetakan Kesebelas, Jakarta, Pradnya Paramita, 1990.

Lay, Cornelis, Involusi Politik: Esai-esai Transisi Indonesia, Yogyakarta, PLOD UGM- JIP UGM, 2006.

M., Sri Soemantri, Bunga Rampai Hukum Tata Negara Indonesia, Bandung, Alumni, 1992.

Ma'shum, Saifullah, KPU dan Kontroversi Pemilu 1999, Jakarta, Pustaka Indonesia Satu, 2001.

MacIver, RM, The Modern State, First Edition, London, Oxford University Press, 1955.

Mahendra, Yusril Ihza, Dinamika Tata Negara Indonesia: Kompilasi Aktual Masalah Konstitusi, Dewan Perwakilan dan Sistem Kepartaian, Jakarta, Gema Insani Press, 1996.

Mahfud MD, Moh., Demokrasi dan Konstitusi di Indonesia, Yogyakarta, Liberty, 1993.

Mahfud MD, Moh., Politik Hukum di Indonesia, Jakarta, Pustaka LP3ES Indonesia, 1998.

Meny, Yves dan Andrew Knapp, Government and Politics in Western Europe: Britain, France, Italy, Germany, Third Edition, Oxford, Oxford University Press, 1968.

Noer, Deliar, Pengantar ke Pemikiran Politik, Jakarta, Rajawali, 1985.

Pamungkas, Sigit, Perihal Pemilu, Cetakan Pertama, Yogyakarta, Laboratorium Jurusan Ilmu Pemerintahan dan Jurusan Ilmu Pemerintahan UGM, 2009.

Pandoyo, S. Toto, Ulasan terhadap Beberapa Ketentuan UUD 1945: Sistem Politik dan Perkembangan Kehidupan Demokrasi, Yogyakarta, Liberty, 1981.

Purnomo, Teguh dan Sukarno, Mengawal Demokrasi dengan Ikhlas, Yogyakarta, Pustaka Pelajar, 2016.

Rozak, Abdul dkk (ed.), Civic Education: Demokrasi, Hak Asasi Manusia dan Masyarakat Madani, Jakarta, ICCE UIN Syarif Hidayatullah bekerja sama dengan The Asia Foundation dan Prenada Media, 2003.

Sagala, Budiman B., Praktek Sistem Ketatanegaraan Menurut UUD 1945, Jakarta, Ghalia Indonesia, 1981.

Salim, Hairus (peny.), Tujuh Mesin Pendulang Suara, Yogyakarta, LKiS, 1999.

Saragih, Bintan R., Lembaga Perwakilan dan Pemilihan Umum Indonesia, Jakarta, Gaya Media Pratama, 1988.

Schattschneider, E.E., The Semisovereign People: A Realist's View of Democracy in America, Illionois, The Dryden Press Hinsdale, 1975.

Simanungkalit, Salomo (Ed.), Indonesia dalam Krisis 1997-2002, Jakarta, Kompas, 2002.

Siregar, Amir Effendi, et al (ed.), Percikan Pemikiran Fisipol UGM tentang Pembangunan, Yogyakarta, Fisipol UGM, 1990.

Sulistyaningsih, Endang, Pemilu dan Perkembangan Demokrasi di Indonesia, Salatiga, Widya Sari Press, 2003.

Thaib, Dahlan dan Ni'matul Huda (ed.), Pemilu dan Lembaga Perwakilan dalam Ketatanegaraan Indonesia, Yogyakarta, Jurusan HTN Fakultas Hukum UII, 1993. 